\title{
“Memórias pesadas": os estivadores do Rio Grande/RS e o golpe civil-militar
}

\author{
"Heavy memories": dockworkers of Rio Grande/rs in the civilian-military \\ coup
}

Thiago Cedrez da Silva

Universidade Federal de Pelotas, Brasil thicedrez@hotmail.com

Edgar Ávila Gandra Universidade Federal de Pelotas, Brasil Universidade do Porto, Portugal edgar_gandra@hotmail.coml

\begin{abstract}
Resumo
O objetivo deste trabalho consiste na análise da trajetória dos trabalhadores da estiva de Rio Grande, durante o ano período de 1964, perpassando o impacto que os acontecimentos do corrente ano implicaram no modo de vida dos estivadores riograndinos. Com nossa proposta, visamos identificar as transformações ocorridas no cotidiano desses obreiros, principalmente dos militantes, evidenciando a relação entre o dia a dia da classe trabalhadora e a sua atividade sindical. Será a partir do estudo da memória reavivada dos nossos protagonistas e do diálogo com as demais fontes, que buscaremos compreender os indícios de autonomia e as formas de resistência ao controle e intervenção de dominação a que foi submetido o Sindicato da Estiva de Rio Grande, durante o final do governo trabalhista de João Goulartt e dos primeiros meses da implantação da ditadura civil-militar de 1964.
\end{abstract}

\section{Palavras-chaves}

História Oral, Memória, Porto de Rio Grande, Estivadores, Golpe Civil-Militar.

\section{Resumen}

El objetivo de este trabajo es el análisis de la trayectoria de los trabajadores de la estiba en Río Grande durante el año 1964, pasando por el impacto que los acontecimientos de aquel año repercutieron en la forma de vida de los trabajadores portuarios rio-grandinos. Con nuestra propuesta, nuestro objetivo es identificar los cambios que ocurrieron en la vida diaria de estos trabajadores, en su mayoría militantes, que muestra la relación entre la vida cotidiana de la clase obrera y su actividad sindical. Será a partir del estudio de la memoria de nuestros protagonistas y el diálogo con otras fuentes, que buscan comprender los signos de la autonomía y las formas de resistencia al control y la dominación de la intervención que sufrió aquel año la el sindicato de estibadores de Río Grande, hacia el final del gobierno laborista de John Goulartt y los primeros meses de aplicación de la dictadura cívico-militar de 1964. 


\title{
“Memórias pesadas"
}

\section{Palabras clave}

Historia Oral, Memoria, Puerto de Río Grande, Dockers, Golpe Cívico-Militar.

\begin{abstract}
The objective of this work is the analysis of the trajectory of the stevedoring workers of Rio Grande, during the year 1964, passing the impact that the current events of the year resulted in the livelihoods of rio-grandinos stevedores. With our proposal, we aim to identify the changes occurring in the daily life of these workers, mostly militants, showing the relationship between the daily lives of the working class and its trade union activity. Will be from the study of memory revived of our protagonists and dialogue with other sources, who seek to understand the signs of autonomy and forms of resistance to control and intervention it has undergone the Union of Stowage of Rio Grande during the late the Labour government of Joao Goulartt and the first months of implementation of the civilmilitary dictatorship 1964.
\end{abstract}

\section{Key words}

Oral History, Memory, Port of Rio Grande, Dockers, Civil-Military Coup. 


\section{Thiago Cedrez da Silva - Edgar Ávila Gandra}

\section{Considerações iniciais}

Este artigo pretende analisar a experiência histórica dos trabalhadores sindicalizados da estiva do Rio Grande/RS no ano de 1964. Entende-se que, após o Golpe Civil-Militar, o Brasil permeou uma fase repressiva em sua história recente. Neste período, ocorreram cassações dos direitos civis, além de perseguições e prisões de líderes sindicais e trabalhadores. Como em todo o país, no sul não foi diferente. Na cidade do Rio Grande, por ser uma cidade portuária e possuir um grande número de indústrias, havia uma quantidade significativa de trabalhadores ligados às militâncias politicas-partidárias que lutavam por melhorias sociais. Aos "olhos" do novo governo, isso significava um problema a ser resolvido, já que por algum tempo esta região se apresentava nos discursos conservadores da mídia local como centro de comunistas, simbolicamente nomeada como a "cidade vermelha" 1 .

$\mathrm{Na}$ medida em que os acontecimentos pós-golpe foram se desenrolando, os sindicatos rio-grandinos sofreram diversas intervenções por parte dos militares, que efetuaram prisões de líderes sindicais. Os trabalhadores tiveram que se adaptar ao novo sistema vigente. Seu cotidiano foi modificado, o medo e a preocupação da repressão passaram a permear o campo de trabalho, o que, de fato, levou a um rearranjo no sistema de resistência ${ }^{2}$ e luta diante das condições que eram postas. Com isso, nosso trabalho visa compreender como se desenrolou essas formas de resistência e seu impacto na vida dos estivadores rio-grandinos.

A partir da memória reavivada dos obreiros da estiva do Rio Grande, buscarse-á evidenciar aspectos do cotidiano no decorrer das transformações políticas e sociais do ano de 1964. A análise dos indícios documentais e das fontes orais forma um campo significativo para abordar questões mais complexas. Nesse sentido, torna-se um campo propício para a utilização do referencial denominado paradigma indiciário ${ }^{3}$, exposto pelo pesquisador italiano Carlo Ginzburg, no qual se faz uma discussão sobre a possibilidade de construir interpretações através de pequenos indícios, "pistas", que proporcionam ao pesquisador refletir sobre a problemática de pesquisa no processo de diálogo com as fontes. Fica claro que estes indícios estão presentes nas lembranças desses trabalhadores e que emergem a partir das contradições, das ambivalências e percepções daqueles que

\footnotetext{
${ }^{1}$ A classe operária rio-grandina desempenhou, em sua trajetória, uma ativa movimentação na vida político-social do município, terminando por moldar uma imagem que pode ser sintetizada na denominação de "Rio Grande, a cidade Vermelha". Essa nomeação é herdeira da intensa da intensa participação dos trabalhadores em processos reivindicatórios, liderados, geralmente, por grupos de esquerda. Para maior entendimento, ver: Athaydes Rodrigues. Agora Eu... A revolução de 1964 em Rio Grande. Porto Alegre, Pallotti, 1980.

${ }^{2}$ No que tange ao conceito de resistência, concordamos com as formulações de Marilena Chaú́. Conformismo e resistência: aspectos da cultura popular no Brasil. São Paulo: Brasiliense, 1986. Para a autora, a "[...] resistência [...] pode ser difusa - na irreverência do humor anônimo percorre as ruas, muros da cidade - quando localizada em ações coletivas e grupais" (pág. 63). Deste modo, podemos afirmar que tal conceito tanto pode ser deliberado como espontâneo, assumindo uma postura multifacetária, e possibilitando uma melhor compreensão das várias formas de resistências, que os trabalhadores da estiva do Rio Grande elaboraram, frente ao contexto histórico em tela.

${ }^{3}$ Carlo Ginzburg. Mitos, emblemas e sinais: Morfologia e história. São Paulo: Companhia das Letras, 1989.
} 
vivenciaram o momento histórico em estudo. Cabe ao pesquisador, filtrar e interpretar as pistas, e assim comparar e dialogar com as fontes documentais.

\section{A História Oral em perspectivas}

Trabalhar com relatos ou testemunhos de agentes comuns que vivenciaram um determinado período histórico, nos permite dar voz a protagonistas sociais geralmente não contemplados nos discursos oficiais. Dentro das inúmeras possibilidades e práticas que a História Oral oferece, optamos por fazer entrevistas temáticas de final aberto ${ }^{4}$. Não existe um método puro, no entanto, essa perspectiva de exposição de um tema com a possibilidade do entrevistado se manifestar de uma forma mais aberta é, no nosso entender, fundamental para a pesquisa que ora propormos, que se caracteriza pelo direcionamento a um tema específico, pelo qual o entrevistador, ao encaminhar a entrevista, possibilita ao entrevistado uma dinâmica mais espontânea e flexível. Além disso, as entrevistas temáticas possibilitam fornecer elementos, informações, versões e interpretações sobre temas específicos. Neste caso, sobre a trajetória de vida dos trabalhadores da estiva, sindicalizados, que vivenciaram o período em tela.

Verena Alberti ressalta o valor da história oral, que consiste em “[...] privilegiar a realização de entrevistas com pessoas que participaram de, ou testemunharam, acontecimentos, conjunturas, visões de mundo, como forma de se aproximar do objeto de estudo". ${ }^{5}$ Ou seja, conhecer as visões dos sujeitos que vivenciaram os acontecimentos históricos é de extrema relevância para nossa pesquisa. Ao mesmo passo que é importante buscar perceber e identificar, nas narrativas dos entrevistados, as possíveis influências do tempo presentes na memória trazida à tona.

Esse cuidado com a memória é importante, pois lidaremos com trabalhadores que vivenciaram um período tensionado da história do Brasil, o Golpe Civil-militar, sendo possível, ainda, encontrar relatos perpassados pelo medo e pelo receio de que certas informações possam comprometê-los. Isto se deve ao fato de que alguns trabalhadores do Porto do Rio Grande - em especial da Estiva terem sido perseguidos, presos e torturados nesse período 6 .

Ao analisar as entrevistas, é preciso estar ciente de que estamos lidando com a memória de pessoas que participaram de inúmeros acontecimentos ao longo de suas vidas. Deste modo, podemos dizer que a memória é objeto de contínua negociação entre diferentes valores e significados que trazem sentimentos de identidade que se alteram continuamente pelas experiências.

As relações sociais existentes entre os indivíduos fornecem bases para uma memória coletiva, sendo a identidade um fator de ligação, de pertencimento dentre um rol de acontecimentos. Com isso, ocorre uma veste de identificação, logo um conflito de representações dentro do palco das relações sociais. Deste modo, "a identidade e diferença são estreitamente dependentes da representação. É por

\footnotetext{
4 Para essa discussão, nos foi útil a obra de José Carlos Sebe Bom Meihy. Manual de História Oral. São Paulo: Loyola, 1996.

${ }^{5}$ Verena Alberti. História Oral: a experiência do CPDOC. Rio de Janeiro: Fundação Getúlio Vargas, 1990, págs. 1-2.

6 No jornal: Jornal Rio Grande, 25/4/1964, p. 1, foi publicado a lista com os nomes das pessoas que foram presas e aquarteladas no Navio Hidrográfico da Marinha Canopus, em Rio Grande, e em seguida transportadas para Porto Alegre. Dentre estes, encontramos portuários, estivadores e ferroviários, membros de categorias atuantes no cenário de luta sindical no município sulino.
} 


\section{Thiago Cedrez da Silva - Edgar Ávila Gandra}

meio da representação, assim compreendida, que a identidade e diferença adquirem sentido". ${ }^{7}$

Dentro dessa discussão, a relação entre memória e História Oral pode ser contínua, e a identidade torna-se um elemento perceptível nas falas dos estivadores rio-grandinos. Sobre essa relação entre memória e identidade, Verena Albert contribui ao afirmar que:

A memória é essencial a um grupo porque está atrelada à construção de uma identidade. Ela [a memória] é resultado de um trabalho de organização e de seleção do que é importante para o sentimento de unidade, de continuidade e de coerência, isto é, de identidade. E porque a memória é mutante, é possível falar de uma história das memórias das pessoas ou grupos, passível de ser estudada por meio de entrevistas de História Oral. As disputas em torno das memórias que prevalecerão em um grupo, em uma comunidade, ou até em uma nação, são importantes para se compreender esse mesmo grupo, a sociedade como um todo. ${ }^{8}$

No ato de relembrar algo, acabamos por reencontrar a nós mesmos, por conseguinte, formamos uma identidade. Esse reencontro torna-se um caminho possível para que os sujeitos trilhem os tempos de sua vida. De acordo com Delgado, a memória atualiza o tempo passado, tornando o tempo vivo e pleno de significados no presente, além se ser inseparável da vivência da temporalidade, do fluir do tempo e do cruzamento de tempos múltiplos. ${ }^{9}$

Sobre memória, existem inúmeras concepções, já que ela não se reduz ao simples ato de recordar. Para Maurice Halbawachs, a memória seria um processo coletivo fruto da interação individual com os outros (o fenômeno social), possibilitando, assim, que as pessoas se lembrem de determinados fatos. ${ }^{10}$ Deste modo, cria-se a concepção de uma memória coletiva cuja formação abrangeria toda a influência da cultura social. Faz sentido analisar o fato de que os indivíduos dialogam entre si, criando-se assim uma linha tênue entre diferença e identidade.

Portanto, com o uso da História Oral, buscaremos compreender quais os olhares dos trabalhadores com relação ao período histórico de luta operária no imediato Golpe de 1964,-visando elencar algumas questões que ficaram implícitas nas falas destes, permeando assim, como afirma Michel Pollack, as "zonas de sombra, silêncios, não ditos". No caso específico, o contexto e os silêncios da resistência dos estivadores rio-grandinos. ${ }^{11}$

Nossa temática de pesquisa se articula a alguns conceitos-chave. Como trabalhamos com um grupo de pessoas que vivenciaram a pesquisa em foco, entende-se a necessidade de analisar e elucidar esses conceitos que permeiam o campo da nossa discussão sobre memória de grupo e/ou classe. 0 conceito de memória foi trabalhado concomitantemente à análise da metodologia. 0 segundo conceito é o de resistência, que, segundo Marilena Chauí, "pode ser difusa - na irreverência do humor anônimo que percorre as ruas, muros das cidades - quanto

\footnotetext{
7 Tomaz T. da Silva (org.). Identidade e diferença: a perspectiva dos estudos culturais. 4ํㅡ. Ed. Petrópolis, Vozes, 2005, pág. 91.

8 Verena Alberti. História Oral: a experiência do CPDOC. Rio de Janeiro: Fundação Getúlio Vargas, 1990, pág. 167.

${ }^{9}$ Lucília Delgado. História Oral- Memória, tempo, identidades. Belo Horizonte, Autêntica, 2006.

10 Maurice Halbawachs . A memória coletiva. São Paulo, Vértice, 1990.

11 Michel Pollack. "Memória, esquecimento, silêncio", Estudos Históricos. Vol. 2, n³, p. 3-15, Rio de Janeiro, 1989, pág. 6.
} 
localizada em ações coletivas ou grupais". ${ }^{12}$ Assim, a resistência assume aspectos de espontaneidade ou pode ainda ser deliberado, assumindo uma conotação mais ampla, o que permite adentrarmos no universo dos trabalhadores da Estiva do Rio Grande e compreendermos as formas de resistência que estes desenvolveram diante da conjuntura que vivenciaram.

No que se refere ao mundo do trabalho, percebe-se, ao longo da década de 1980, a emergência de tendências historiográficas que enfatizavam as diferentes expressões históricas da classe operária, seja seus modos de viver, o cotidiano de trabalho que se expande além dos muros das fábricas e locais de labor, abandonando visões deterministas explicativas que focavam nos aspectos econômicos e políticos muito presentes na literatura sobre o movimento operário nas décadas de 1960-70 no Brasil. É referencia dessa mudança a incorporação pelos historiadores brasileiros dos trabalhos dos marxistas ingleses, em especial de Eric Hobsbawn e E. P. Thompson, que ainda inspiram um debate profícuo, que também serve de escopo para esse artigo. Aliás, essa perspectiva se desdobrou em outras análises por parte da historiografia sobre o trabalhador, como, por exemplo, sobre o cotidiano, cultura popular etc.

Encontra-se imerso nesse ponto as práticas cotidianas aos níveis públicos e privados, ao econômico e político. Será a partir desta concepção que analisaremos o cotidiano dos obreiros estivadores rio-grandinos, principalmente as rupturas que ocorreram com o advento do Golpe de 1964, pois serão percebidas mais adiante, nas falas dos entrevistados, que as tensões que havia antes da mudança política e social se perpetuam no modo de vida dos obreiros rio-grandinos.

Uma transformação profunda e muito abrupta gerou medo e insegurança no cais portuário, visto que, em um espaço de tempo muito reduzido e sobre coação, foram alteradas diversas rotinas de trabalho e socialização. 0 sistema vigente exigiu que essa classe de obreiros redimensionasse suas atitudes, na luta por direitos. Digno é o fato de manterem a intencionalidade de lutar por direitos mesmo no ambiente de tensão que se instalou após o golpe. Edificou-se uma readaptação por parte dos trabalhadores em busca da retomada das conquistas e do enfrentamento com os setores golpistas que comandavam o porto e o país.

\section{Estiva do Rio Grande}

O nosso objeto de estudo está voltado para o trabalhador da estiva, responsável pela movimentação e ajuste de cargas nos porões ou sobre o convés de embarcações, sendo imprescindível para a execução do transporte marítimo. Diferente de outros grupos de operários do porto, o estivador, entre outras particularidades, só trabalha a bordo, nunca em terra. Os obreiros que ficam sobre as carretas ou vagões do lado de fora são os arrumadores de cargas. Já o pessoal das pranchetas e anotações, são os conferentes; e os portuários são os responsáveis pelo transporte e manutenção de cargas no cais do porto, através de atividade braçal, denominada de capatazia.

Até a primeira metade do século $\mathrm{XX}$, os estivadores tinham a tarefa de embarcar a carga nos navios e fazer o serviço de bordo. Com o tempo, a atividade

\footnotetext{
12 Marilena Chauí. Conformismo e resistência: aspectos da cultura popular no Brasil. São Paulo: Brasiliense, 1986, pág. 63.
} 


\section{Thiago Cedrez da Silva - Edgar Ávila Gandra}

foi sendo separada e delimitada, ficando no cais os portuários e a bordo os estivadores. ${ }^{13}$

Devido ao fato de Rio Grande possuir o único porto oceânico do estado e ser um centro de escoamento e recebimento de produtos agropastoris do continente, posteriormente comercial e industrial, houve uma intensa atividade comercial durante todo o século XIX e início do XX. Para Carlos Alberto de Oliveira, Rio Grande, por ser um ponto de encontro das águas salgadas do Oceano Atlântico com as águas doces da Laguna dos Patos, possui características significativas:

[...] o Porto de Rio Grande é muito mais do que um lugar aonde mercadorias e insumos chegam e partem para todas as partes do Brasil e do mundo. 0 Porto é a alma da cidade e a relação existente entre eles e os costumes dos Rio-grandinos são bastante peculiares. Desde o linguajar, tudo em Rio Grande lembra o Porto. Na cidade, muitas são as famílias que possuem, ou possuíram ao menos um representante que trabalhe direta, ou indiretamente no Porto. ${ }^{14}$

No mesmo sentido do autor, destacamos o caráter portuário da cidade do Rio Grande, desde sua edificação enquanto urbe, sobrelevando a tradição das atividades da estiva neste espaço. Logo, no final do século XIX, surgiram as organizações de estivadores, que era primeiramente associada à Sociedade União Operária ${ }^{15}$ (SUO) do Rio Grande. Esta organização de perfil corporativo tinha como objetivo criar condições de amparo e sobrevivência para seus associados, que vivenciavam um cotidiano de trabalho precário, marcado por longas jornadas, pouca segurança e vigilância constante por parte da guarda portuária.

$\mathrm{Na}$ medida em que os trabalhadores da estiva foram se organizando, por questões como controle de trabalho, caráter sazonal de contratação de mão de obra, somados às péssimas condições laboriosas, a entidade começou a ganhar força. Nessa época (1900-1930), os operários de "carga e descarga" dos navios mercantes eram escolhidos por capatazes ligados às agências de navegação, ou firmas estivadoras.

Diante de tais questões e anseios, organizou-se, no dia 7 de outubro de 1931, o Sindicato dos Operários da Estiva, para a luta pelos seus direitos e pela

\footnotetext{
13 Sobretudo a partir do surgimento da Consolidação das Leis Trabalhistas-CLT, conforme o Art. 257, que estabelece o seguinte: "a mão de obra na estiva das embarcações [...] só poderá ser executado por operários estivadores ou por trabalhadores em estiva de minérios nos portos onde os houver especializados, de preferência sindicalizados, devidamente matriculados nas Capitanias dos portos ou Agências".

${ }_{14}$ Carlos Alberto de Oliveira. O estivador no Sindicalismo. Rio de Janeiro: Alves Pereira Editores, 1999, pág. 34.

${ }^{15}$ Fundada em 24/12/1893 e fechada pela ditadura em 1964. Segundo Beatriz Loner, em inícios de 1936, começou-se a organizar a União Sindical, tendo a participação de Carlos Santos, Deputado Classista e do inspetor do MTIC, Jacuy Magalhães (Evolução 2/2/1936). Beatriz Ana Loner. "Centrais Operárias de Rio Grande", Francisco das Neves Alves. Por uma história multidisciplinar do Rio Grande. Rio Grande, Fundação Universidade Federal do Rio Grande, 1999, págs. 207-211. Criada em 20 de fevereiro com os sindicatos: dos carpinteiros, Estiva, Conferentes, Práticos, Maquinistas e Motoristas, Padeiro, Porto e Barra, Fiação e Tecelagem, Charuteiros, Magarefes, Gráficos, Comércio e SUO. (Evolução 80/3/1936). Ela Congregava mais sindicatos do Porto que outras centrais, mas não conseguiu manter um funcionamento regular, existindo apenas intermitentemente. Um dos motivos mais evidentes dessa fraqueza organizativa foi o aumento do nível de repressão, depois da revolta da ANL. Em Janeiro de 1937, fez-se nova tentativa de reorganização da União Sindical, pelos 18 sindicatos mais organizados (Evolução 10/1/1937), iniciando-se um trabalho um pouco menos intermitente, mas truncado pela decretação do Estado Novo.
} 
distribuição equitativa de serviço. Esta entidade tinha o papel de organizar o sistema de captação de mão de obra, fazendo a intermediação entre trabalhador e empregador.

Sobre a fundação do corrente sindicato, o depoimento de Alcer da Silva Moraes $^{16}$, um membro da Entidade Estivadora do Rio Grande, é elucidativo para entender a percepção desses sobre a fundação do sindicato:

[...] foi motivado pelo desejo e pela necessidade de operários em busca do bem comum da atividade profissional, ele foi fundado em 7 de outubro de 1931 e tem um documento, que nós temos aqui que é a ata número 1. Este fato aconteceu com 196 operários, e esta ata foi encerrada na, às 11 horas, do dia 7 de outubro de 31 . Tendo naquela oportunidade sido eleito presidente o senhor João Batista de Paula Ramos. Começou, assim, o sindicato a dar os primeiros passos, justamente porque são operários aqui do Rio Grande. [...] naturalmente eles foram adquirindo independência socioeconômica e foram comprando os seus terrenos e sua sede própria. Essa sede aqui [sede atual do sindicato, situado na Rua 24 de maio, no 673], ela deve ter sido adquirida em 1938-39, justamente pelo primeiro presidente João Batista de Paula Ramos. [...] eles eram tirados para o trabalho em regime de semiservidão, isto é, os tomadores de serviço tinham os seus capatazes [ligados às Agências de Navegação, ou Firmas Estivadoras] e esses escolhiam os operários, sem o mínimo critério de escalação, de rodízio, de número. Então havia discriminação, um processo discriminatório, e isto é interessante relatar, porque estes capatazes subiam num pedestal, e os operários que, na época, eram verdadeiros changueiros [cavalos para pequenas corridas], em volta dele, e ele escolhia o mais forte, o mais grande para o trabalho de estiva, em detrimento daquele mais humilde, mais fraco e isso não...faz com o trabalho digno, da pessoa, do trabalhador.

Fica evidente na fala acima a ação dos trabalhadores para melhorias nas condições de trabalho e o agenciamento da mão de obra. Através da negociação direta entre trabalhadores e patrão, soma-se o destaque da forma como era feita a distribuição de trabalho.

A partir dessas mudanças, a entidade assumiu o controle do movimento de inclusão-exclusão no mercado de trabalho portuário vinculado à atividade de estiva, introduzindo inclusive o regramento do que viria a se tornar a "força supletiva". O próprio sindicato estabeleceu normas para a entrada de membros "provisórios" em momentos de grande movimentação e carência de sindicalizados para efetivar todas as tarefas. 0 sistema sazonal de trabalho realizado no universo portuário sempre teve, como elemento de fundação, a existência do excedente/ausência da mão de obra. Tal autonomia em organizar e distribuir a força de trabalho trouxe um fortalecimento da condição de sócios do Sindicato, passando a considerar que, na medida em que há um maior poder da entidade, há um maior prestígio dos estivadores. ${ }^{17}$

0 "fazer-se" da construção da classe estivadora em Rio Grande foi marcado por lutas e reivindicações de seus trabalhadores por melhorias de condições de

\footnotetext{
16 Entrevista realizada por Carmen Helena Braz Mirco, em 8 de outubro de 1986. Grifo do autor. 17 Carlos Alberto de Oliveira. $O$ estivador no Sindicalismo. Rio de Janeiro: Alves Pereira Editores, 1999.
} 


\section{Thiago Cedrez da Silva - Edgar Ávila Gandra}

trabalho e de ganhos. Na fala de Cristóbal Moraes ${ }^{18}$, percebemos a importância do sindicato para a categoria.

[...] o período anterior da fundação do Sindicato foi de muitas perseguições, efetuadas pelas autoridades constituídas da época a mando do capital dominante. 0 Sindicato dos Estivadores de Rio Grande é o quarto sindicato da categoria a ser criado no Brasil, sendo que o primeiro é do porto de Salvador em 1912, seguido de Paranaguá e Antonina em 1919 e o Sindicato de Itajaí 1922. [...] é importante salientar que, anteriormente, já havia as Associações de Estivadores de Recife, fundada em 1891, e em 1903, a União dos Operários Estivadores do Rio de Janeiro. [...] a História do Sindicato dos Estivadores de Rio Grande, como os demais da categoria, foi marcada por lutas constantes nas reivindicações dos direitos trabalhistas em defesa de seus operários, prova disso, em 1933, foi efetuado o primeiro Congresso Nacional de Estivadores, com o objetivo principal de fundar a Federação Nacional dos Estivadores, que infelizmente não houve consenso, dado as circunstâncias políticas da época, vindo a ser fundada somente no ano de 1949.

A fala de Cristóbal nos permite compreender, a partir da experiência do mesmo, que o cotidiano desta categoria, desde sua gênese, assim como no caso dos portuários, foi marcado por lutas e reinvindicações dos direitos e uma significativa organização sindical e política. Isso demonstra a preocupação dos estivadores por reconhecimento e unidade, aspecto importante na sua luta cotidiana por direitos. Destarte, percebemos que os membros do Sindicato da Estiva do Rio Grande estiveram presentes nos Congressos Nacionais dos Estivadores, acompanhando e lutando em prol de melhorias para a categoria.

O exemplo dessa participação foi visto no III Congresso Nacional dos Estivadores, ocorrido em $1^{\text {o }}$ de agosto de 1960, na sede do Sindicato dos Estivadores de Santos, que teve como representante o rio-grandino Epahim Lacerda de Morais, também na $2^{\circ}$ Conferência Nacional dos Estivadores, em Salvador, em 25 de abril de 1963, com a participação dos representantes riograndinos Jovenal Antônio Vieira, Telmo Porto, Zalmiro Pacheco. ${ }^{19}$ No decorrer da entrevista com Cristóbal Moraes, percebemos que a conquista de direitos que a entidade adquiriu se sobressaia em suas lembranças. Isso demonstra a importância que tiveram tais modificações, pois afetaram diretamente sua rememoração do passado da Entidade. Esse aspecto pode ser observado na fala a seguir:

Em 1940, foi aprovada a tabela que disciplinava os trabalhos sem produção; 1949, a conquista do repouso remunerado; 1954, Segundo Congresso Nacional dos Estivadores, com a regulamentação do serviço de estiva; 1955, ganhos para cargas de riscos e inflamáveis; 1956, regulamentação dos serviços de estiva nas equipes (ternos) a bordo dos navios, a ser executados por estivadores escalados no rodízio, pois que até então os serviços de chefias de equipes (ternos) eram executados por operários designados pelos patrões (agentes de navegação); 1960, Terceiro Congresso Nacional dos Estivadores, com participação efetiva e atuante do Sindicato de Rio Grande, representado pelo incansável mentor, relator e associado: Efraim

\footnotetext{
${ }^{18}$ Cristóbal S. Moraes é membro do Sindicato dos Estivadores e dos Trabalhadores em Carvão e Mineral de Rio Grande, Pelotas e São José do Norte. Trabalha nesta entidade desde a década de 1950, e atualmente exerce a função de secretário.

${ }^{19}$ Carlos Alberto de Oliveira. $O$ estivador no Sindicalismo. Rio de Janeiro: Alves Pereira Editores, 1999.
} 
Lacerda de Moraes, da inclusão de chefias no sistema de rodízio sindical dos associados; em 1960 a 1/08, greve geral dos estivadores em prol da conquista de Férias, aumento nas taxas de produção em 35\%, fornecimento de água potável nos porões, adicional de 20\% nos serviços ao largo, retorno a Caixa Acidente; 1966, Rodízio de capatazia, a exemplo das chefias de ternos, estes também eram designados pelos patrões. ${ }^{20}$

O sindicato na vida dos estivadores do Rio Grande deixa de ser apenas uma entidade de representação de classe e passa a se enraizar na vida dos obreiros. Percebe-se, a partir dos depoimentos, o quanto o Sindicato foi importante na vida desses trabalhadores, pois por meio dele, melhoraram de situação social, adquiriram melhores ganhos financeiros. Para Cristóbal Moraes, o sindicato representou "como emprego, significa tudo, como profissional, digamos assim, empregado, pra mim eu gosto demais. Isso aqui faz parte da minha vida. Pra mim, serve como um todo, até porque eu já sou descendente praticamente, já está no DNA, meu pai era estivador." 21 Destaca-se ainda que o sindicato torna-se mais importante na medida em que se entrelaçavam aspectos privados e públicos dos estivadores. Nosso entrevistado, Alcer da Silva Moraes ${ }^{22}$, nos traz a seguinte rememoração:

[...] é a minha vida, praticamente toda ela é ligada à atividade laborativa do sindicato, já que com 30 anos de empregado nesta organização, e em função dela, e a maneira como a gente adquiriu os conhecimentos, motivados naturalmente pelo desejo de conhecimentos, motivados naturalmente pelo desejo de conhecimentos posteriores ao da organização sindical, eu até dou uma definição disto: que uma vez eu tive uma ocasião, de dar a um ministro, perguntando por que eu gostava tanto do sindicato? Como eu entendia sindicato, e pra mim, o que era sindicato? Respondi ao mesmo que o sindicato pra mim era cachaça [vício]. Justamente por esta participação afetiva e de tantos anos na lida operária, então o campo de ação, da classe operária, principalmente desta atividade, que é a dos estivadores, é um campo extraordinário, e que a gente que lida com isso e vive com isso, torna-se até apaixonante.

Percebemos, nessas memórias, como o sindicato aparece de forma basilar na mudança das vidas desses trabalhadores. Além disso, é evidente, na fala do Sr. Alcer Moraes, assim como nas de "Tobal", uma ligação entre vida e sindicato, demonstrando o grau de entrelaçamento entre vida privada e relação com a entidade de classe que representavam.

Antes da implantação do Golpe Civil-Militar, os trabalhadores lutavam por seus direitos através de paralisações no Porto do Rio Grande. Geralmente, as decisões dessas ações eram feitas em conjunto com outros sindicatos de estivadores de outros portos espalhados pelo Brasil. Era comum também a união com outras categorias portuárias, como por exemplo, os trabalhadores do cais, para agregar força no movimento. Mesmo com os conflitos internos entre cada uma, havia uma consciência de classe entre as categorias de trabalho no que tange à luta por direitos. "Havia uma unidade sindical muito forte", diz Cristóbal Moraes.

\footnotetext{
20 Disponível em: < http://www.estivarg.com.br/php/historia.php > Acesso em: 10 Mar. 2014.

21 Entrevista realizada pelo autor, em 14 de agosto de 2012.

22 Entrevista realizada por Carmen Helena Braz Mirco, em 8 de outubro de 1986. Grifo dos autores.
} 
No que tange ao cotidiano de trabalho desses obreiros, ressaltamos alguns aspectos de sua rotina. Após terem passado pela "chamada" 23 , os mesmos se dirigiam aos navios para começarem suas atividades de estivar. As condições de trabalho eram adversas, e muitas vezes causavam sequelas à saúde após anos de trabalho nesta função. Para aumentar sua renda, muitos chegavam a virar dois ciclos de trabalho no mesmo dia, ou seja, trabalhavam em mais de uma escala. Cristóbal Moraes fornece algumas informações sobre o cotidiano de trabalho de um estivador dentro do navio:

[...] foi criado escalas A, B, C, e D, com dois a mais, dois a menos, dependendo da carga, era navio aquela coisa toda, mas dá até ali, dependendo da produção do navio né, teoricamente essa carga aqui vai dá mais dinheiro do que a caixa mais alta, muitas vezes até acontece de nem te dado mais dinheiro, mas teoricamente ela dava mais, então era distribuído assim o rodízio, e o horário era quatro, mais quatro, mais duas horas, então tu trabalha das, vamos supor, das sete e meia até às onze e meia. Fazia o serviço, aí o navio continua na tarde, ficava engajado pra tarde. Se o navio continuasse trabalhando nesse período inteirinho aqui, das onze e meia à uma e meia, aí tu participava também com um salário diferenciado, era uma hora e meia em dobro, ganhava seis mais quatro, uma hora e meia em dobro, um período de almoço e $100 \%$ também na parte das quatro, das quatro da tarde, se esse navio prorrogasse ou prolongasse mais duas horas, ia das cinco às sete, mais duas horas ganha mais $20 \%$. [...] às sete hora entrava outro grupo, era distinto, terminava um grupo, vamos supor, corrido no caso que to citando, terminava às sete horas, sete horas entrava outro grupo. [0 trabalho] era braçal mesmo porque tinha na época, tinha lotação de couro salgado ainda, mesa de pedra... Isso era movimentado, fardos de lã, aquilo vinha já da zona de produção, bem compactada. E aqueles fardos de lã é em torno de $300,400 \mathrm{~kg}$ por aí, então tu... A lingada ${ }^{24}$ dos navios era antiga, não tinha um porão totalmente aberto, tinham as cobertas. A coberta é o quê? Protege o porão aqui, isso aqui é o navio, essa folha aqui é o navio, abria o porão aqui, então tem essa coberta aqui e tem que botar a carga aqui em baixo. Hoje os porões já abrem direto, então o que acontece se desce a lingada aqui no meio, a gente tem que botar aquele fardo lá no canto, tem que levá no muque né, bota em cima de algum estrado, alguma coisa é sempre braçal.

Muitas vezes, o trabalho braçal era exaustivo e perigoso devido à falta de equipamentos de proteção adequados, o que acabava em acidentes. Cristóbal relata ainda como era o sistema de trabalho e os acidentes que ocorriam ${ }^{25}$ :

Tinha, por que... Até porque as cargas, principalmente por problema de carga, pó, contaminação, outra que a gente cita que o operário não queria usar material de proteção. Os materiais de proteção muitas vezes não são adequados pra esforço físico, bota uma máscara, não consegue desempenha teu mesmo desempenho do que sem a máscara num trabalho braçal, então achava melhor não usa. Vou-te citá o caso das areias que o pessoal chamava aí, que são os adubos, fertilizantes, tinha máscara. 0 sindicato fornecia máscara, mas tira grande parte das condições físicas

\footnotetext{
23 Segundo Carlos Alberto de Oliveira. Quem é do mar não enjoa: Memória e Experiência de Estivadores do Rio Grande/RS (1945- 1993). São Paulo, PUC, 2000. Em Rio Grande, o local de Chamada ficava a poucos metros do Portão principal do Porto Novo, o Portão 4. Lá se situava a "roda da estiva", o local de engajamento do trabalho (pág. 81).

${ }^{24}$ Expressão utilizada pelos trabalhadores do porto, que consiste na transferência da carga do cais para dentro dos navios nos porões.

${ }^{25}$ Denominação que Cristóbal Moraes diz que os colegas da estiva o chamam.
} 
de trabalho porque são quatro horas no mínimo que tu tá trabalhando ali com esforço físico, respirá com o nariz livre é uma coisa, com o nariz com uma máscara é diferenciado. Já diminui o oxigênio, a quantidade, até pelo calor também porque aquilo é uma carga que aquece no porão, no verão pior ainda, então achava melhor trabalha sem a máscara, na pior das hipóteses botava a máscara, e hoje tá se usando mais essas pequenas aí de apoio, de contato com o rosto. Mas antes o cara precisava até inclusive pegá um sutiã usado da mulher, corta e bota um elástico e trabalha enchendo caçamba, então obviamente que incidência de doença era maior. ${ }^{26}$

No dia a dia de trabalho, os estivadores laboravam em ternos, um para cada guindaste e outro para cada porão. Se o terno tivesse doze homens, oito trabalhavam no porão, e quatro no convés. Destes, dois cuidavam do guindaste, e os outros permaneciam no portaló como ajudantes, pois a borda da escotilha impedia que o guindasteiro visse precisamente onde estava sendo depositada a carga. Os contramestres seguiam, por sua vez, a orientação do contramestre geral do navio, ou o capataz que se subordinava ao encarregado da firma estivadora. ${ }^{27}$

O comentário a seguir, de Cristóbal pode nos ilustrar um pouco como eram as formas de resistência dessa categoria, antes do Golpe Civil-militar de 1964, diante das condições em que viviam:

As greves antes, pelo menos no nosso setor, o nosso setor era bem unido e tinha um comando que era a federação que existe até hoje, que em minha opinião é inoperante hoje, não se atualizou, tinha um comando geral no Rio de Janeiro e era muito, principalmente no segmento dos portuários, era muito unido, havia uma necessidade dos marinheiros, marinha mercante, reivindicar um direito que o governo tava ameaçando de não querer dar. Essa federação se unia e fazia greve geral. Então na época, até a partir de... o Osvaldo Pacheco mandava parar, a partir de quarta-feira, vamos paralisar todos os portos do Brasil em função a adesão à greve dos marinheiros, digamos assim. Tinha essa unidade sindical bem atuante que foi desmanchada, fechada, parava tudo! Tinha a Tartaruga também, pra não prejudicar total, pra não parar todo o segmento, então uma empresa tal, X lá, tá com problema de pagar, não, vamos fazer a "Operação Tartaruga" [Diminuição do ritmo de trabalho] na empresa, se a outra paga, por que tu não vai pagar? Havia uma unidade sindical.

Direcionando nosso olhar para os reflexos que as mudanças políticas do ano de 1964 tiveram no cotidiano dos estivadores rio-grandinos, veremos que, na véspera do dia $1^{\mathrm{o}}$ de abril, alguns trabalhadores faziam uma leitura de que o momento político tensionado podia levar a radicalizações que modificariam o sistema de governo vigente. Para Cristóbal Moraes:

[...] no dia seguinte já, no transcorrer do dia pra outro, na noite anterior, já tava se prevendo que ia haver um golpe e como realmente houve. [...] isso daí era interesse de capitalismo, de capital né, de reverter a situação que tava se propiciando uma virada para o socialismo. Então o capital americano, principalmente que é o que domina, não queria, foi até por sinal quem mais deu apoio pro Golpe de 64 no Brasil, e foi isso, os Estados Unidos, porque segundo comentários da época, a guarda

\footnotetext{
26 Entrevista realizada pelo autor, em 14 de agosto de 2012.

27 Segundo Carlos Alberto de Oliveira. Quem é do mar não enjoa: Memória e Experiência de Estivadores do Rio Grande/RS (1945- 1993). São Paulo, PUC, 2000
} 


\section{Thiago Cedrez da Silva - Edgar Ávila Gandra}

armada americana já estava a postos lá para, já estava a caminho da costa brasileira, né, pra dizer: Ou vocês mudam, ou nós invadimos. Era o que se supunha.

Logicamente, no cotidiano de trabalho, o debate político sobre o contexto que vivenciavam estava presente. Mesmo com trabalho exaustivo e com longos períodos de trabalho, a consciência do momento não era impedida, nem debates e reflexões sobre como agir diante dessa conjuntura. Deve-se ressaltar que, até março de 1964, o sindicato tinha significativa autonomia e lutava pelos direitos dos seus trabalhadores. Estes eram atuantes, mobilizando-se e organizando-se para lutar por seus direitos e melhores condições de renda e trabalho. Contudo, com o Golpe de 1964, essas ações tiveram que ser adaptadas frente ao cenário de perseguições e prisões políticas e sindicais.

\section{"No transcorrer do dia pra outro": a memória do Golpe de 1964}

Trabalhar com História Oral e, em especial, sobre a memória do Golpe de 1964, ainda é um assunto delicado. Isso porque encontramos certa resistência ao abordar tal temática no nosso diálogo com os entrevistados. Percebe-se certo medo ainda presente na memória desses trabalhadores. Os silêncios que permeiam suas falas estão carregados de receio ao tratar de determinados assuntos, buscam proteção no "não dito". Em linhas gerais, um silêncio auto imposto como regra de sobrevivência para o tempo da ditadura ainda persevera na memória desses sujeitos.

A propulsão desses silêncios dificilmente é rompida, por isso vê-se necessário, como nos afirma Pollack, tê-los como objeto de análise. "Essa tipologia de discursos, de silêncios, e também de alusões e metáforas, é moldada pela angústia de não encontrar uma escuta, de ser punido por aquilo que se diz, ou, ao menos, de se expor a mal-entendido". ${ }^{28}$ A História Oral, por mais que se proponha a ser essa escuta, é apenas um elemento que se destina a ouvir, enquanto outras fontes, escritas, por exemplo, mantem-se em silêncio se não forem interrogadas. Esse, na maioria das vezes, não pode ser interpretado como opcional; é, sim, uma imposição social. Um jogo de força e poder que elabora o que se pode revelar sobre a história nacional e o que deve remeter ao esquecimento coletivo. Neste sentido,

[...] o golpe é, simultaneamente, produto e produtor desse sentimento. É produto quando analisado sob o prisma dos agentes sociais que o articularam, pois partilhavam um significativo temor de mudanças em seus status quo. Possuíam receio e medo de perder seus privilégios, suas posições e suas propriedades. ${ }^{29}$

Daí a necessidade de atentarmos aos indícios "ditos e não ditos" pela fonte oral, já que estamos trabalhando com a rememoração de experiências individuais sobre um período que causou e deixou marcas significativas na história de vida de pessoas que vivenciaram o ano de 1964. Com ressaltou Gandra, no trecho acima, os trabalhadores tinham medo de perder seus direitos adquiridos, bem como de

\footnotetext{
28 Michel Pollack. "Memória, esquecimento, silêncio", Estudos Históricos. Vol. 2, n³, p. 3-15, Rio de Janeiro, 1989, pág. 6.

${ }^{29}$ Edgar Ávila Gandra. O cais da Resistência: a trajetória do sindicato dos trabalhadores nos serviços portuários de Rio Grande no período de 1959 a 1969. Cruz Alta, UNICRUZ, 1999, pág. 89.
} 
sofrer as consequências repressivas por estarem em uma categoria combativa e atuante.

Diversos sindicatos sofreram intervenções dos militares em todo o país. 0 Sindicato dos Estivadores do Rio Grande, logo após a tomada de poder pelos militares, sofreu uma intervenção através de uma invasão na sede da entidade. Cristóbal Moraes relata que:

[...] Com relação ao ano de 1964, a época do Golpe de 64.0 ano de 64 terminou com, pra mim, na minha forma de pensar, foi com, o estopim foi com o comício no Rio de Janeiro, o comício na Cinelândia no Rio de Janeiro, no dia 31 de março, onde tava as confederações juntamente apoiando o governo de João Goulart, mas o golpe já estava preparado, começou com Minas Gerais. Então, dia 1ํ do mês de Abril, até se não me engano, dia dos bobos, eles começaram a invadira as federações, pegaram inclusive a nossa federação, tinha uma reunião lá da categoria, de todo o segmento portuário daquela época, e os fuzileiros navais invadiram a sede da federação, prenderam alguns componentes nossos, inclusive um representante nosso, Almir Pacheco Martins, que era delegado nosso junto à federação, que o sindicato tem, né? Tem sempre um representante quando há congresso ou reunião da federação, vai um ou dois representante, na época tava esse tal de Almir Pacheco que prenderam e levaram para a penitenciária. Um mandatário nosso que era o Osvaldo Pacheco, conseguiu fugar do barco e ali pegou outros componentes de outras associações e aquilo desencadeou por todo o Brasil Aqui em Rio Grande, eles invadiram o sindicato aqui, ao invadir o sindicato prestaram a voz para toda a popularização. Eu estava [na sede do sindicato neste dia] tinha gente aqui, inclusive um funcionário mais velho estava fora e quando quis entrar não deixaram. Carregaram seus fuzileiros navais, aí quem tava fora não entrava e quem tava dentro não saía, até eles vasculharem toda a documentação. Ficaram em torno de umas duas horas aí, vasculhando, mas não levaram nada de elementos bons que pudessem condenar alguém, não. Nesse meio tempo, o nosso presidente, que um dia antes tinha feito uma passeata... Fugiu! E até então nunca mais soubemos dele 30 .

Para ilustrar com mais detalhes o episódio da invasão, a fala de João Batista de Oliveira é muito enriquecedora, pois demonstra as ações rápidas dos militares e a preocupação do desmantelamento da organização sindical para o êxito dos planos do golpe.

[...] $\mathrm{Na}$ tarde 31 de março, véspera do golpe o conselho de representantes da Federação dos Estivadores estava reunido na sua sede à rua Santa Luzia, 173-7o andar, quando foi invadida pela polícia do Governador Lacerda. Eu podia me livrar facilmente porque no momento não me encontrava no salão de assembleia, mas preferi ir me juntar aos demais companheiros. Muitos, dos que fugiram, foram presos quando saíram do elevador. Quando o oficial da polícia deu ordem de prisão a todos que se encontravam no recinto e cuja ordem não acatada, eles responderam com bombas de gás lacrimogêneo. A maioria conseguiu se transferir para a sala da tesouraria e reforçar a porta com o cofre impedindo a entrada dos soldados que ficaram ameaçando atirar caso não nos entregássemos. Como continuamos irredutíveis, eles começaram a jogar bombas de efeito moral, como chamam, dentro do salão, pela janela. Eu, mais outro, apanhávamos as bombas e por outra janela, as jogávamos todas para o lado do prédio da Aeronáutica que era contíguo ao nosso. Graças a isto, veio um oficial superior da Aeronáutica e dispersou os policiais. Naquela ocasião, pensávamos que se tratava apenas de mais uma provocação do

30 Entrevista realizada pelo autor, em 14 de agosto de 2012. 


\section{Thiago Cedrez da Silva - Edgar Ávila Gandra}

Governador ou dos outros órgãos reacionários, mas na verdade, já se tratava do golpe. Sabedores que fomos que vários companheiros, dos que conseguiram fugir da reunião, foram presos, como: Jose da Luz, Luiz de Oliveira Junior (Rio de Janeiro) ,Wallace Perruche (Canavieiras) e muitos outros, procuramos no refugiar no subúrbio da capital. Sendo aconselhado pelo companheiro Pacheco que podia retornar ao trabalho e a minha casa e família. [...] As prisões continuaram, e os estivadores combativos, principalmente os presidentes de Sindicatos, como: Dominguinhos (de Santos), José Pinto Madureira (em Ilhéus). Pretextato José da Cruz (de Natal) conseguiu escapar por se achar no Rio de Janeiro; Antogildo Paschoal Viana (de Manaus), tesoureiro da Federação, foi encontrado morto no terraço do hospital do IAPETC, não se sabendo, até hoje, se foi jogado ou se suicidou. Posteriormente, foram presos: Eufraiano Nunes Galvão, Francisco Alves da Costa, estivador e deputado do Estado do Rio de Janeiro, Eduardo José dos Santos e Benedito José dos Santos, estivadores do Rio de Janeiro e muitos outros por todo Brasil. Uma pequena parte dos presidentes de sindicatos dos estivadores que não foram perseguidos nem presos, ficou comprovado que viviam dentro do movimento arrastados pelas circunstâncias, mas ligados ao mesmo tempo à reação. ${ }^{31}$

A onda de prisões que aconteceu não foi diferente no Rio Grande do Sul. Em Rio Grande, os líderes sindicais foram presos e levados ao encarceramento no navio hidrográfico Canopus. Dois dirigentes do Sindicato dos Trabalhadores Portuários do Rio Grande foram presos: Dinarte Luz Alves e Antônio Nailem Espíndola. Este último, na época, fazia parte do Sindicato dos Portuários, mas em 1980, ingressou no Sindicato dos Estivadores do Rio Grande, aposentando-se nesta instituição. Antônio Nailem Espíndola nos relata com detalhes como foi este episódio e sua estadia a bordo do navio usado como prisão flutuante:

[...] Bom, eu fui preso dentro do Porto quando cheguei há uma hora, de manhã, fui distribuir o trabalho. Estavam todos meio apreensivos porque diziam que iam ter prisões, porque nós havíamos resistido no início. Eu falei que não ia me esconder que eu não tinha cometido crime algum. 0 que eu fazia, no caso, era defender o trabalhador. Então, quando eu cheguei há uma hora, o inspetor Ernani Freire, que era o chefe da guarda do porto, aí ele me chamou e falou que o delegado regional queria falar comigo. Quando eu cheguei lá, ele me deu voz de prisão. Me disse: "Você está preso por ordem do Ministério da Marinha”. Aí eu pedi para me explicarem o motivo da minha prisão. Aí, ele me disse que não tem nem explicação, mandou me examinar para ver se eu não tinha arma, e logo chegou um jipe e me levaram para o capitão, e ele me disse de novo: "você está preso em nome da lei". E eu pedi por que. Aí ele me disse: "não tem explicação". Me mandou para o navio Canopus. Lá encontrei um pessoal da viação férrea e já começou a chegar mais gente, daí chegou Dinarte, capitão Athaydes". [...] e daí fomos colocados ali, um monte de homens dentro de uma pecinha que tinha cinco metros quadrados. A gente dormia num beliches e a comida vinha para a gente, o vigia nos alcançava por uma frestinha. A pessoa não podia nem conversar, não podia ouvir rádio, não podia ler jornal, não podia se comunicar com a família. ${ }^{32}$

Existia uma importante simbologia ao encarcerar os trabalhadores portuários em um navio. Tal prisão possibilitaria dois focos de análise:

\footnotetext{
${ }^{31}$ Carlos Alberto de Oliveira. $O$ estivador no Sindicalismo. Rio de Janeiro: Alves Pereira Editores, 1999, págs. 154-5.

32 Entrevista realizada por Edgar Ávila Gandra, com Antônio Nailem Espíndola, em 25 de fevereiro de 1997.
} 
0 primeiro refere-se ao fato de que os afastando do contexto social da cidade eliminavam sua capacidade de influenciar os outros segmentos sociais em atitudes contrárias aos ideais revolucionários. E o segundo caracteriza-se pelo impacto psicológico do aprisionamento dos portuários em seu próprio instrumento e local de trabalho: o navio. ${ }^{33}$

Além das prisões de alguns membros do sindicato, outras mudanças alteraram o cotidiano desses trabalhadores. No pós-golpe civil-militar, as greves e paralisações que antes eram constantes, já não aconteciam. Mas mesmo com poucas opções para agir, os trabalhadores se organizavam e agiam de forma clandestina. Era comum, neste período, os trabalhadores combinarem entre si e realizarem a "operação tartaruga" 34. Segundo Cristóbal Moraes, "pra não prejudicar total, pra não parar todo o segmento, então uma empresa tal, X lá, tá com problema de pagar, vamos fazer a "operação tartaruga" na empresa. Se a outra paga, por que tu não vai pagar? ${ }^{35 " .}$

0 choque que o golpe trouxe nos ganhos salariais sempre esteve presente nas falas dos depoentes. Na medida em que, havia mudanças na legislação, o salário era condensado, deixando de existir os adicionais separados, como era antes. Cristóbal Moraes sentiu na pele essas perdas. Segundo nosso depoente:

[...] a estiva principalmente, sempre teve uma tabela, bem, como é que vou te dizer, assim, bem, uma remuneração dela, é a tabela que remunera a estiva, mas bem elástica porque tu teria... bem definida, porque tu tem 100\%. Sempre foi feito assim, mais os adicionais correspondentes, horas extras, periculosidade, etc., tudo discriminadamente. Manda, manda, tu não tem um salário complessivo ${ }^{36}$. Então, o que aconteceu com a ditadura impostas pelos milicos, os militares, esse salário teu aqui que dizia que tu tinha 100 mais 18, 16 e 666. Na época, ganhava repouso semanal, trabalhava aos domingos, né, trabalhador eventual. Então, tu não tem os descansos de domingo. Então esse percentual compensa cada vez que tu trabalha. Isso tudo aqui eles disseram assim: a taxa, tá tudo dentro da taxa, salário complessivo. Então tu não sabia o que tu ganhava, sabia que tinha uma taxa, a taxa de janeiro era aquela, deu. Mas o que tava contido ali dentro não sabia. Então era, cumpra-se, determina-se e cumpra-se. ${ }^{37}$

Devido ao fator da impossibilidade de se executar uma greve aos moldes dos anos anteriores a 1964, entrou em cena uma figura importante, no refazer-se da luta dos estivadores em busca de seus diretos: o advogado. Assim, por meio do encaminhamento à justiça, os trabalhadores continuavam suas reivindicações, mas muitas vezes demorava para se obter o resultado da luta. Os estivadores, antes de 1964, recorriam à justiça para rever questões que não estivessem de acordo com a lei e seus direitos, mas a partir de 1964, intensificavam-se as ações judiciais, sendo o caminho mais adotado depois do fechamento do regime. Prova disso é que os

\footnotetext{
33 Edgar Ávila Gandra. O cais da Resistência: a trajetória do sindicato dos trabalhadores nos serviços portuários de Rio Grande no período de 1959 a 1969. Cruz Alta, UNICRUZ, 1999, pág. 94.

34 A operação tartaruga refere-se a uma diminuição no ritmo de trabalho de modo que houvesse um atraso na carga ou descarga das mercadorias dos navios para o cais portuário.

35 Entrevista realizada pelo autor, em 14 de agosto de 2012.

36 Quer dizer que determinada importância ou percentagem para atender englobando vários direitos legais ou contratuais do trabalhador.

37 Entrevista realizada pelo autor, em 14 de agosto de 2012. Grifos e observações do autor.
} 


\section{Thiago Cedrez da Silva - Edgar Ávila Gandra}

diretos perdidos com o Golpe de 1964 só foram sendo retomados a partir de 196668. Em entrevista, Alcer da Silva Moraes descreve a importância de se ter uma representação jurídica ativa através do advogado:

Esse sindicato é pioneiro no Brasil, em busca de soluções jurídicas para seus problemas. [...] dado às dificuldades de pressão pelo Movimento de 64, ele [o sindicato] passou a reclamar, naturalmente por, pelo "omele legis" [sic], criado na legislação do trabalho, após o movimento de 64 [...], ou seja, uma desorganização planejada para confundir os direitos então conquistados da estiva, gente vai ter grandes prejuízos com naquilo que era direito adquirido. Então este sindicato de Rio Grande, uma tática diferente, como não podia fazer pressão e ameaça de greve, partiu então em busca da solução dos problemas para a discussão jurídica de fato ${ }^{38}$.

Por fim, ao nos referirmos sobre o significado e os desdobramentos do Golpe de 1964 em suas vidas, os entrevistados demonstraram a visão de estagnação em suas vidas e no país, de modo que a ditadura, além de toda repressão social e política, realizada através das cassações dos direitos constitucionais e das torturas físicas e psicológicas na população, trouxe um sentimento de fragilidade financeira e social nas vidas dos estivadores do Rio Grande. Para Alcer da Silva Moraes, “o movimento de 64 prá nós foi justamente uma parada na organização operária, uma estancada na organização operária." Cristóbal Moraes complementa dizendo que:

O significado eu não sei te dizer exatamente, nada, [o Golpe de 1964] não resolveu nada, foi até uma estagnação temporária aqui pra nós, eu acho que não só pra nós, pra sociedade toda brasileira que, aliás, isso aí foi um segmento que se desenvolveu pela América do Sul toda. [...] 0 reflexo positivo eu não vejo, e negativo foi temporário, até porque a gente conseguiu recuperar os direitos anteriores depois ${ }^{39}$.

Os trabalhadores, mesmo passando por um estado de policiamento, por parte dos militares, de suas ações, e sentido os reflexos do golpe já nos primeiros meses de 1964, continuaram a se organizar e readequar suas estratégias de luta por melhorias para a categoria. Seja no dia a dia do trabalho, com a diminuição do ritmo de trabalho em momentos de resistência a situações desfavorecedoras, ou nas reuniões, fora do sindicato, em locais comuns como em algumas residências deles mesmos. Também em meio ao futebol e à sinuca no bar, os anos que sucedem esse período, permitem aos trabalhadores continuarem unidos na luta pela classe e por direitos.

\section{Considerações Finais}

Nesse texto, observa-se que os processos de fazer-se e refazer-se estão presentes na formação identitária dos estivadores, aspecto frequente na sua labuta diária e na defesa coletiva de seus interesses.

Ao visualizarmos, de forma breve, as experiências de estivadores do Rio Grande, no ano de 1964, conseguimos compreender alguns motivos que levaram à consolidação o Sindicato dos Estivadores do Rio Grande. Na teia de

\footnotetext{
38 Entrevista realizada por Carmen Helena Braz Mirco, em 8 de outubro de 1986. Grifo do autor.

${ }^{39}$ Entrevista realizada pelo autor, em 14 de agosto de 2012. Grifo do autor.
} 


\section{"Memórias pesadas"}

acontecimentos, ressalta-se a ação dos trabalhadores em lutar pelos seus direitos. Isso demonstra que esta categoria buscava uma "voz ativa" e isso contribuiu significativamente na luta operária da cidade e do país. Outro aspecto que convém ressaltar é que essa luta dos estivadores, tendo em vista que a urbe, por ter em sua origem a formação portuária e industrial como característica, mesclava-se na representação de resistência operária do município em apreço.

Em referência à memória do golpe entre os estivadores, é perceptível, de forma latente, ainda hoje, como um acontecimento que causou dificuldades na luta operária, prejudicando suas vidas através das bruscas transformações no modo de vida desses trabalhadores, principalmente no que tange aos salários dos mesmos. Foi significativo o arrocho salarial instituído, que causou um intenso e permanente clima de insegurança, somado à repressão do período aos militantes, tanto que, nas entrevistas, as conversas sempre terminavam com referência à cassação dos direitos adquiridos e suas consequências nos salários. Quanto ao medo, que perdurou na cidade e entre os trabalhadores no período, ainda produz ecos no presente, pois identificamos que os depoentes apresentavam certa resistência ao falar sobre certos assuntos ligados à luta sindical.

No nosso entender, a memória dos estivadores sobre o golpe permite uma aproximação sobre o tencionado período e como ele impactou os trabalhadores, a ponto de ser destacado em todas as falas que analisamos. Logo, como amostragem, fica evidente o ambiente de insegurança financeira e medo da repressão política. 0 golpe é muito mais do que um momento de repensar na vida operária. Eles não repensam a vida, eles sofrem diretamente com a repressão e a adoção de novos mecanismos de exploração. Essa mudança no tecido social que cobria o sindicato é um rico filão de trabalho.

Também é digno de nota o processo de desestabilização organizado pelo movimento e a ação golpista que incidiu bruscamente no cotidiano dos trabalhadores da estiva. Apesar de apresentarmos uma leitura e interpretação sobre um recorte específico e temporal que foi o ano de 1964, salientamos que nosso trabalho contribui para o enriquecimento da gama historiográfica sobre a luta operária, em especial sobre a categoria estivadora do Rio Grande. Claro que nossa pesquisa está longe de esgotar as informações existentes, mas tem o desafio de fomentar o aprofundamento de diversos pontos em outras pesquisas de maior fôlego.

Recibido: 01/07/2015

Evaluado: $31 / 07 / 2015$

Versión Final: 20/08/2015 